\title{
U progu biznesu - All seasons hotel - Koncepcja dla firmy Wiśniowski
}

\section{The business project - All seasons hotel - Concept for Wisniowski company}

\section{Streszczenie}

Tendencje rozwoju przemysłu hotelarskiego świadczą o nasilającym się dążeniu do poszerzania oferowanych usług. Królują obiekty wielofunkcyjne, hybrydowe, o elastycznej ofercie, które są w stanie sprostać oczekiwanemu obrotowi finansowemu. Politechnika Krakowska, nawiązując współpracę z firmą Wiśniowski, umożliwiła studentom Wydziału Architektury stworzenie projektów koncepcyjnych hybrydowego hotelu nad Jeziorem Rożnowskim. Uczestnicy zmierzyli się z wymaganiami wobec architekta od strony planowania biznesowego, starając się osiągnąć kompromis pomiędzy zasadami dobrego rzemiosła a ekonomią użytkowania.

Słowa kluczowe: hotel, współpraca, hybryda, biznes

\section{Abstract}

The trends in the development of the hotel industry are the evidence of an intensifying drive to expand the amount of services they offer. The dominant are the multifunctional, hybrid, flexible ones, which are able to meet the expected financial expectations. Cooperating with Wiśniowski company, the Cracow University of Technology enabled the students of the Architecture Faculty to create conceptual designs for a hybrid hotel by the Rożnowskie Lake. Participants were able to meet the architectural requirements from the business planning point of view, trying to reach a compromise between the principles of good craftsmanship and the economics of use.

Keywords: hotel, cooperation, hybrid, business 


\section{WSTĘP}

„To, za co naprawdę płacisz, to okazja by na noc lub dwie stać się osobą, którą naprawdę

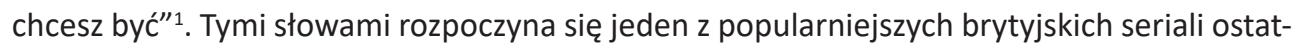
nich lat - Hotel Babylon, traktujący o życiu codziennym gości i obsługi jednego z luksusowych londyńskich hoteli. Słowa te można odnieść także to determinant decyzji projektanta, którymi są tu ludzkie potrzeby i finanse.

Podkreśla także fakt, że pobyt w hotelu nie musi wiązać się jedynie z podstawowymi potrzebami, ale także z fantazjami, by znaleźć się w innej rzeczywistości, którą architekt ma okazję stworzyć.

W wyniku prowadzenia dialogu pomiędzy Wydziałem Architektury a samorządami miejskimi, a także przedstawiecielami biznesu, powstało wiele innowacyjnych projektów studenckich, które służą nie tylko jako uczelniane koncepcje, ale także jako inspiracje dla potencjalnych inwestorów. W 2016 roku Wydział Architektury Politechniki Krakowskiej nawiązał nawiązano współpracę z firmą Wiśniowski, w wyniku której powstały cztery studenckie koncepcje 5-gwiazdkowego centrum rekreacyjno-hotelowe w Gródku nad Dunajcem, nad Jeziorem Rożnowskim. Uczestnicy projektu mieli możliwość kontaktu z inwestorem i zmierzenia się z wymaganiami wobec architekta od strony ekonomii i biznesu.

Autorka, w poniższym artykule, prezentuje fragmenty pracy teoretycznej dotyczącej projektowania hoteli, w oparciu o literaturę i badania własne, a także przedstawia swoją koncepcję dla firmy Wiśniowski, która jednocześnie stanowiła projekt dyplomowy autorki².

\section{ZARYS HISTORII HOTELARSTWA}

Historia hotelarstwa sięga najwcześniejszych manifestacji kultury człowieka. Pierwsze podania z nim związane znajdujemy w Biblii. Starożytni Grecy budowali łaźnie i termy, by zapewnić odpoczynek i regenerację. Rzymianie jako pierwsi zapewniali schronienie podróżnych w misjach politycznych. Pompeje z kolei charakteryzowały się już skomercjalizowanym rynkiem hotelarskim. Wraz z upływem czasu sposoby komercyjnego przyjmowania gości przybierają formę coraz bardziej uprzemysłowioną.

Początek przemysłu hotelarskiego powinien być datowany na XV w. Francuskie prawo wymagało, aby lokale oferujące noclegi prowadziły rejestr gości, co pozwoliło na obserwowanie rozwoju tej dziedziny. Rozwijający się przemysł hotelarski w Europie zaczął łączyć się z innymi gałęziami biznesu, co zwiększało zysk oraz popularność obiektów o szerszej ofercie. Na początku XVIII wieku przy Placu Vendôme w Paryżu można było zobaczyć pierwszy przykład wielofunkcyjnego kompleksu mieszczącego butiki, biura, apartamenty, hotele, przekształcając te ostatnie w bardziej dostępne i skomercjalizowane przestrzenie (do dziś: „Hôtel de Vendôme”) 
Po II wojnie światowej rozwój przemysłu hotelarskiego nabrał prędkości i rozwijał się także poza granicami dużych miast. Powstawały pierwsze ośrodki narciarskie w Szwajcarii, np. Saint-Moritz, Gstaad w stanie Montana, a następnie - pierwsze morskie ośrodki rekreacyjne. W latach 70. odkryto sektor biznesowy jako okazję dla stworzenia hoteli nowej generacji. W tym czasie wielki rozwój można było zaobserwować w miastach Bliskiego Wschodu, takich jak Dubaj czy Abu Dhabi. Duża gama obiektów hotelarskich, które zapewniano, współpracowała z dobrze rozwiniętym sektorem lotniczym.

Z czasem trendy w hotelarstwie zaczęły zmieniać się, rozszerzając zakres usług. Gość o zróżnicowanych potrzebach: rodzina z dziećmi, biznesmen czy osoba starsza, stał się ważnym odbiorcą i potencjalnym klientem. Rozwój przemysłu hotelarskiego obserwujemy od jego początków po dzień dzisiejszy, a jedną z głównych widocznych tendencji rozwoju jest poszerzanie wachlarza usług oraz spectrum osób, dla których dedykowany jest hotel ${ }^{4}$.

Hotelarstwo to branża wysokiej konkurencji. Podróżowanie po całym świecie staje się coraz łatwiejsze i tańsze. Dziś podróżuje każdy, nie tylko osoba o wysokim statusie majątkowym. Z drugiej zaś strony można zaobserwować rywalizację wśród luksusowych kompleksów o najwyższym standardzie, zwłaszcza na terenach Bliskiego Wschodu, takich jak Abu Dhabi czy Dubaj. Tamtejsze inwestycje o dużej skali łamią światowe rekordy w wysokości budynku, kosztów, wielkości itp. Imponujące zasoby finansowe i wielkie przestrzenie w rozwijających się miastach dają możliwość "starchitektom” projektowania architektury prestiżowej. Wysoka częstotliwość nowych inwestycji hotelowych sprawia, że kraje Bliskiego Wschodu są liderami dzisiejszego komercyjnego przemysłu hotelarskiego.

Historia hotelarstwa świadczy o tym, że wraz z rozwojem dąży do poszerzania oferowanych przez siebie usług. Królują obiekty wielofunkcyjne, hybrydowe, o elastycznej ofercie, które same mogą stanowić atrakcję dla klienta lub opowiadają historię, która intryguje. Prowokuje to do powstawania obiektów w przeróżnych stylizacjach (il.1, 2)

\section{TYPOLOGIA HOTELARSTWA}

Typologia hotelu może być dokonana na podstawie różnych czynników, takich jak rozmiar, standard, funkcja, własność, grupa docelowa klientów itd.

Jedną z powszechnie stosowanych klasyfikacji hoteli jest przyznawanie gwiazdek, a zdobycie każdej z nich jest potwierdzeniem standardu hotelu. Wymagania dotyczące uzyskania gwiazdki są precyzyjnie określone, a dotyczą rozwiązań w dużej skali (np. funkcje całego kompleksu) jak i w małej (np. minimalny rozmiar pokoi, wielkość tóżek, a nawet ilość wieszaków w szafach). Możliwe jest nagradzanie kompleksu tytułem hotelu 5-gwiazdkowego deluxe - jest to standard najwyższy (możliwe jest, w potocznym zrozumieniu, usłyszeć też 
o hotelach 6- lub 7-gwiazdkowych). Konieczne jest także zapewnienie najwyższego standardu w zakresie np. reprezentatywnej architektury, żywności, personelu, lokalizacji, wyposażenia, atrakcji itd. ${ }^{6}$

Nieraz typ hotelu jest ściśle związany z korzyściami, jakie przynosi jego lokalizacja. Hotel uzdrowiskowy kojarzy się z terenem rekreacyjnym: nad morzem, jeziorem, w górach itp. Hotel biznesowo-handlowy będzie profitował w połączeniu z dużymi miastami i centrami biznesowymi. Te z kolei mogą być obsługiwane także przez mniej popularne na świecie, ale częste w Japonii - hotele kapsułowe - np. jako rozwiązanie dla pracowników, którzy po całym dniu pracy w biurze spóźniają się na ostatni pociąg do satelitarnej miejscowości pod Tokio, w której mieszkają. Z kolei hotele lotniskowe są bazą noclegową dla tych, którzy zatrzymują się w podróży, a także dla załogi linii lotniczych?

Istnieją cechy, które tworzą osobny rodzaj obiektów hotelowych. Hotele typu Suite oferują nie tylko tradycyjne pokoje, ale przede wszystkim całe apartamenty. Prowadzi to również do innego czynnika determinującego typ hotelu - długości pobytu. Bed\& Breakfast i hotel standardowy proponują krótki pobyt, nawet na jedną noc. Ale hotele typu Suite i hotele Extended Stay zapewniają warunki do życia w hotelu przez długi czas. Możliwe jest podpisanie umowy na pokój/apartament na wyłączność np. na okres roku - to rozwiązanie powszechnie praktykowane przez biznesmenów i gwiazdy np. w trasach koncertowych. Obiekty te nazywane są również Serviced Apartments ${ }^{8}$.

Boatel (hotel dryfujący np. Boater Riverdream w Renmark, Australia), Boutique hotel (słynący z wyjątkowo dobrego smaku wnętrz, luksusu i wyrafinowania, np. Queen Boutique Hotel w Krakowie), czy hotele lodowe to inne przykłady typów hoteli ściśle związanych z charakterystycznymi cechami obiektu.

Lodowy hotel to miejsce, w którym można spędzić noc w temperaturze oscylującej pomiędzy 5-7 stopni Celsjusza, w budynku z lodu, śniegu i światła (np. Icehotel, Marknadsvägen, Szwecja).

Korzystanie z takiej usługi to przykład obrazujący jeden z trendów w projektowaniu hoteli. To właśnie wnętrze, a także związane z nim możliwości i doznania jest głównym celem przyjazdu gościa. Jest to trend przeciwny do tradycyjnego, w którym hotel traktowany jest jako baza noclegowa i przestrzeń do regenracji przed i po aktywności „na zewnątrz”. Powstają nadal także obiekty ekstrawertyczne, które oferują niezwykłą perspektywę, aby docenić zalety otoczenia. Ta gałąź branży hotelarskiej ciągle rozwija się i jest niezwykle kreatywna (il. 3-5).

Kolejnym podziałem typologicznym - może mniej ważnym dla gości, acz najważniejszym w kwestii ekonomicznej - jest własność. Hotel może być pojedynczą inwestycją, prowadzoną przez prywatnego właściciela lub jednym z wielu w sieci hoteli, których działaność rozprzestrzenia się nawet na cały świat. Jedną z najpotężniejszych korporacji działających w tym sektorze jest brytyjska grupa hoteli InterContinental, która posiada 7 niezależnych firm hotelarskich ${ }^{9}$. 
Czasami już sama forma hotelu może wskazywać na jego własność. Niektóre z sieci mają skłonność do tworzenia duplikatów swoich obiektów w różnych miejscach, niezależnie od tzw. genius loci lub zwyczajnie nie respektując otaczającego je środowiska (il. 6-8). Przeciwieństwem tego zjawiska są hotele wyjątkowe, „szytę na miarę” dla danej lokalizacji. Wiąże się to z dużym zaangażowaniem i dbałością ze strony właściciela. Łatwiej jest o dobry przykład poza listą hoteli sieciowych. Jest to wybór między tanim prêt-a-porter lub wyrafinowanym haute couture w przemyśle hotelarskim.

Hotel Blow Up 5050 w Poznaniu jest przykładem wyjątkowym. Łączy w sobie najlepsze cechy dobrego dizajnu, technologii i sztuki. Projekt został zainspirowany filmem Michelangelo Antonioniego „Powiększenie” (Blow Up). Wejście prowadzi przez Blow Up Hall, bez recepcji. Gość otrzymuje iPhone'a, prowadzącego go przez obiekt do właściwego pokoju, który - co zaskakujące - wybiera jego, nie na odwrót. Hotel Blow Up 5050 jest interaktywnym dziełem sztuki ${ }^{10}$.

\subsection{HOTELE JAKO EKONOMICZNE HYBRYDY}

Obrót finansowy w przemyśle hotelarskim jest ogromny. Rosnąca konkurencja, a także uwarunkowania społeczno-polityczne sprawiają jednak, że rynek ten jest także niestabilny i wiąże się z ryzykiem. Sektor hotelarstwa ma istotny wkład w gospodarkę europejską: w 2010 r. wspierał ją na około 16,6 mln miejsc pracy ${ }^{11}$, a udział w produkcji wynosił ponad $8,1 \%$ całkowitej produkcji gospodarczej ${ }^{12}$. Tak intensywny obrót kapitału sprawia, że wydajność finansowa w hotelach prestiżowych musi być dokładnie zaplanowana.

Główne źródło dochodów hotelu pochodzi z wynajmu pokoi. Jeśli kompleks spełnia potrzeby klienta na przestrzeni całego roku, dochód powinien być względnie uśredniony i możliwy do przewidzenia. Jeżeli jednak działaność hotelu jest związana z wybraną porą roku, często wzbogadza się ofertę hotelu o dodatkowe, wewnętrzne funkcje, niezależne od sezonu.

Salon fryzjerski, spa, basen, saunarium, zaplecze fitness i odnowy biologicznej, sklepy, bary, restauracje, usługi biznesowe lub centrum konferencyjne to niektóre z funkcji, które powinny być dostępne w pięciogwiazdkowym hotelu, który staje się wielofunkcyjną hybrydą. Standard wzrasta natychmiast, ale wartość inwestycji także. Kosztowna jest budowa, utrzymanie i wynagrodzenia osób zatrudnionych. Jeśli właściciel hotelu zdecyduje się na szeroki wachlarz oferowanych funkcji, musi stworzyć kompleks o dużej ilości pokoi hotelowych, aby inwestycja zwróciła się w formie wynajmu. Im większy hotel, tym więcej funkcji oferuje i odwrotnie ${ }^{13}$.

Przykłady wielkoskalowych hybrydowych obiektów hotelowych (il. 9). 


\section{UWARUNKOWANIA PROJEKTOWANIA ZESPOŁU HOTELOWEGO}

Projektowanie hoteli może przebiegać w zależności od kontekstu lub w oderwaniu od niego. Przykładem nawiązującym do otoczenia może być Hotel Bostalsee (il. 10).

Czterogwiazdkowy hotel i kompleks spa, zaprojektowany przez studio GRAFT, usytuowany jest w Saarland, w Niemczech. Jest przykładem obiektu położonego w kontekście naturalnego krajobrazu. Znajduje się nad jeziorem, na stromym terenie, a otaczająca go architektura jest rozproszona i rzadka. Wielkość inwestycji jest adekwatna do charakteru miejsca i dostosowana do rzeźby terenu, w którym duża część geometrii budynku chowa się. Jest to obiekt, który czerpie to, co najlepsze z otoczenia i nie stara się go zdominować. Oferuje usługi związane z rekreacją na jeziorze, dla niewielkiej liczby gości - 100 pokoi ${ }^{14}$.

Innym przykładem jest Hotel Yas w Abu Dhabi, zaprojektowany przez Asymptote Architecture w 2010 roku. Jest to duża inwestycja, zawierająca, wśród dodatkowych funkcji, ponad 500 jednostek pokojowych. Pod mostem łączącym dwie hotelowe wieże biegnie tor wyścigowy Formuły 1, zapewniając gościom niepowtarzalny widok i charakterystyczną atrakcję. Kompleks hotelowy jest dominantą na wyspie Yas - inwestycji o wartości 36 miliardów dolarów ${ }^{15}$ (il. 11).

Architektura powinna być projektowana w zgodzie z otoczeniem. W środku dużego miasta, jakim jest Abu Dhabi, pojawia się hotel dostosowany do jego skali - Hotel Yas. W krajobrazie, w którym natura jest najcenniejszym czynnikiem otoczenia - Hotel Bostalsee - inwestycja znacznie mniejsza, cicha i subtelna.

Autorzy koncepcji dla firmy Wiśniowski znaleźli się w trudnym położeniu. Wolą inwestora było stworzenie co najmniej 500-pokojowego kompleksu hotelowego, w otoczeniu, które pozwala na budowę obiektu o połowę mniejszego. Jednak proces tworzenia architektury jest również sztuką kompromisu - tym razem pomiędzy zasadami dobrego rzemiosła a ekonomią użytkowania. Zamiarem inwestora było stworzenie kompleksu pełnego usług takich jak spa, baseny, gastronomia, centrum konferencyjne itp., które będą stanowić atrakcję dla gości przez cały rok. Najważniejsza z nich to sala wielofunkcyjna, która dzięki swej elastyczności może służyć nawet jako kilka jednocześnie funkcjonujących, konferencyjnych pomieszczeń lub jako sala koncertowa o powierzchni ponad $2000 \mathrm{~m}^{2}$.

\subsection{PROJEKT HOTELU ALL SEASONS, W GRÓDKU NAD DUNAJCEM (AUT. MAŁGORZATA PETELENZ)}

Gródek nad Dunajcem jest niewielką miejscowością położoną w województwie małopolskim. Większość zabudowy w Gródku to budynki mieszkalne i towarzyszące im budynki gospodarcze. Układ przestrzenny jest chaotyczny. Intensywność zabudowy, jak i ilość przestrzeni publicznych maleje wraz z wzrostem odległości od centrum miejscowości.

Celem projektu było utworzenie ekonomicznie wydajnego kompleksu hotelowego, a także przestrzeni uczęszczanej również przez mieszkańców okolicy. Jako pierwszy etap realizacji 
autorka zaproponowała więc promenadę wiodącą wzdłuż brzegu od centrum miejscowości lub od Hotelu Lemon Resort do miejsca nowej inwestycji. Drugi etap przewiduje przedłużenie linii promenady łączącej ją z zaproponowaną siecią transportu wokół jeziora (niezależny bus i sieć wypożyczalni rowerów). Promenada jest nie tylko przestrzenią komunikacyjną. Powinna być także wzbogacona o przestrzenie publiczne, małą architekturę i usługi (sklepy, kawiarnie, kąpieliska, stacje wypożyczenia rowerów itd.) ${ }^{16}$.

Kompleks zapewniający ponad 500 jednostek hotelowych to duża inwestycja, na dużym obszarze (49 823,3 m2), jednak w cichym otoczeniu. Głównym zamysłem projektantki było zarazem sprostanie wymaganiom Inwestora, jak i uszanowanie skali otoczenia.

Jedną z pierwszych zasad kreowania przestrzeni było utworzenie mniejszej kubatury w obszarach sąsiadujących z istniejącą zabudową i większej interwecji w przestrzeni od nich odsuniętej, odseparowej zielenią wysoką. Styczność z najbliższą zabudową istniejącą ma miejsce w południowej części działki, która sąsiaduje z domami mieszkalnymi, 2/3-kondygnacyjnymi.

\subsection{ZASADY PROJEKTOWANIA ZESPOŁU HOTELOWEGO}

W zamyśle przestrzennym zastosowano 3 główne sposoby podziału przestrzeni - dwa horyzontalne i jeden wertykalny.

Pierwszy podział horyzontalny wiąże się bezpośrednio ze skomunikowaniem działki z otoczeniem. Południowa jej część, dedykowana jest, poza ruchem pieszym, także ruchowi kołowemu i wiąże się z głównym placem. Nowa zabudowa stanowi kurtynę pomiędzy dwoma strefami. Pas znajdujący się w północnej części działki przeznaczony jest jedynie dla ruchu pieszego, zielenii, rekreacji i prowadzi dialog przestrzenny z jeziorem.

Kolejny podział horyzontalny związany jest z podziałem funkcjonalnym układu. Wjazd na działkę odbywa się z południowo-wschodniej części i ruch przesuwa się w kierunku zachodnim. W ten sposób również zmienia się charakter zabudowy - od najbardziej publicznego, po bardziej intymny. Części publiczne mają funkcjonować także niezależnie od działania hotelu, by zapewnić sobie szersze grono klientów i większy obrót finansowy.

Podzial wertykalny przestrzeni, również wiąże się z podziałem funkcjonalnym. W parterach umieszczone zostały funkcje usługowe, by mogły być powszechnie dostępne. Pokoje hotelowe umieszczono w wyższych partiach budynków, by zapewnić jak najlepszy widok z okiem i uniknąć kolizji komunikacyjnej. Część hotelowa składa się z 516 pokoi zróżnicowanych pod kątem standardu, wielkości, wyposażenia i charakteru widoku z okna.

Złożoność całego kompleksu wymaga licznych powiązań funkcjonalnych i komunikacyjnych między jego częściami. Mała skala zabudowy otoczenia sugeruje, by zastosować możliwie jak najbardziej rozbitą bryłę. Dlatego też wszystkie budynki usługowe połączone są przestrzenią wspólną w części podziemnej. Od parteru w górę odczuwalne są jako odseparowane bryły. Przerwy między nimi pozwalają na komunikację i utrzymanie kontaktu 
wzrokowego z jeziorem. Dzięki nim także część wiatrów wiejących od strony jeziora nie jest blokowana przez pełną elewację. Powyższy podział przestrzeni sprawia,że główna komunikacja wzdłuż wnętrz kompleksu odbywa się na poziomie -1 .

Apartamenty wolnostojące to przykład rozdrobnienia formy w sąsiedztwie z niewielką zabudową istniejącą. Zostały przewidziane w zachodniej części działki - schowane w rzeźbie terenu i zieleni. Są alternatywym wyborem dla gości, którzy chcą zatrzymać się w hotelu, ale preferują kameralne warunki pobytu. Istnieje 8 małych domów otoczonych zielenią. Znajdują się w najgłębszej części działki, najbardziej odległej od drogi, samochodów i obiektów użyteczności publicznej. Domy są połączone zadaszoną ścieżką prowadzącą do restauracji i najbliższych obiektów, jak pokój do medytacji, pokój jogi czy herbaciarnia.

Ze względu na dużą skalę hotelu sposobem do osiągnięcia również rodzaj intymnego charakteru miejsca jest utworzenie kilku mniejszych wnętrz urbanistycznych. Jedyna duża otwarta przestrzeń znajduje się w południowej części działki. Jej rozmiar ma przede wszystkim spełniać rolę funkcjonalną ${ }^{17}$.

Skala tak dużego założenia może być przytłaczająca dla gości. Przestrzenie społeczne i publiczne przede wszystkim mają za zadanie sprawić, by użytkownicy czuli się swobodnie i komfortowo. Forma zabudowy przypominająca w planie układ dłoni z rozszerzonymi palcami, daje możliwość podziału przestrzeni na kilka mniejszych, zielonych i rekreacyjnych wnętrz (pow biologicznie czynna - 35,22\%).

Także promenada została wzbogacona o przestrzenie publiczne, jak otoczenie - plaża nowego zbiornika wodnego. Jezioro Rożnowskie jest atrakcyjnym miejscem dla turystów, jednak jest zaśmiecone, a poziom wody zmienia się w ciągu roku nawet o 6 metrów. W ofercie nowego kompleksu hotelowego, oprócz wewnętrznego basenu, pojawia się pomysł zwiększania funkcjonalności jeziora. Niezależny zbiornik wodny zasilany jest przez wodę z jeziora, wraz z oczyszczalnią. Ponadto poziom wody w nim może być kontrolowany i niezależny od poziomu wody jeziora.

\section{PODSUMOWANIE}

Tendencje rozwoju przemysłu hotelarskiego świadczą o nasilającym się dążeniu do poszerzania oferowanych usług. Królują obiekty wielofunkcyjne, hybrydowe, o elastycznej ofercie, które są w stanie sprostać oczekiwanemu obrotowi finansowemu. Wnioski z pracy teoretycznej na temat projektowania hoteli, a także dyskusje z inwestorem, autorka potraktowała jako fundamenty, na których zbudowała projekt Hotelu All Seasons, który wpisuje się we wspomniany trend. Głównym założeniem było stworzenie wielkoskalowego kompleksu o szerokiej ofercie usług, przy jednoczesnym ukształtowaniu formalnym pozwalającym na dostosowanie się do kontekstu otoczenia. Przy pomocy rozwiązań przestrzennych dokonała także próby odpowiedzi na potrzeby mieszkańców Gródka nad Dunajcem, łącząc je z oczekiwaniami inwestora i własnymi przekonaniami. 

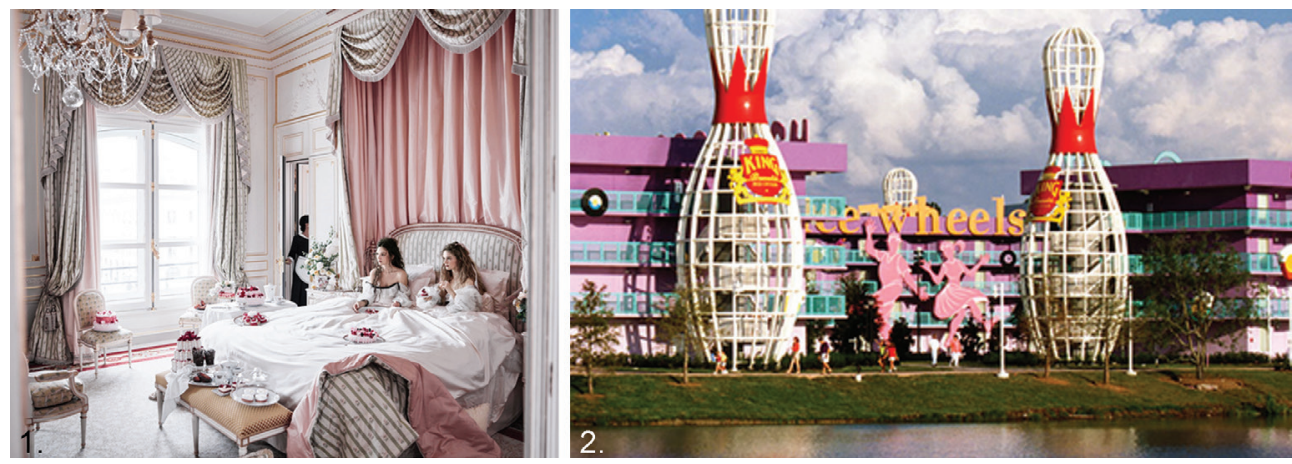

II. 1. Wnętrze hotelu Ritz w Paryżu. Aut. Mikael Jansson dla Vogue w 2016 (źródło: http:// vogue.com/13446877/ritz-paris-grand-opening-versailles-chanel)

III. 1. Hotel Ritz interior in Paris Aut. Mikael Jansson for Vogue in 2016

II. 2. Disney's Pop Century Resort Buena Vista Lake, Floryda, Stany Zjednoczone (źródło: https://disneyworld.disney.go.com/resorts/pop-century-resort) III. 2. Disney's Pop Century Resort Buena Vista Lake, Florida, USA
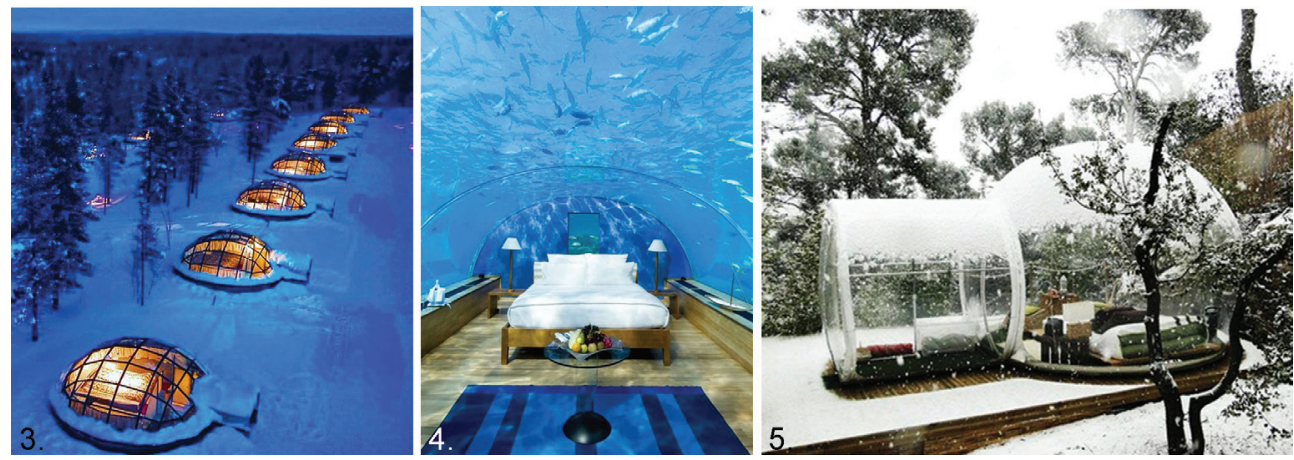

II. 3. Kakslauttanen Arctic Resort, Saariselka, Finlandia (źródło: http://telegraph.co.uk) III. 3. Kakslauttanen Arctic Resort, Saariselka, Finland

II. 4. The Manta Resort - Pemba Island, posesja Psv-zanzibar, Tanzania (źródło: http://themantaresort.com)

III. 4. The Manta Resort - Pemba Island, Psv-zanzibar estate, Tanzania II. 5. Attrap'Reves Hotel (źródło: http://attrap-reves.com/en) III. 5. Attrap'Reves Hotel 

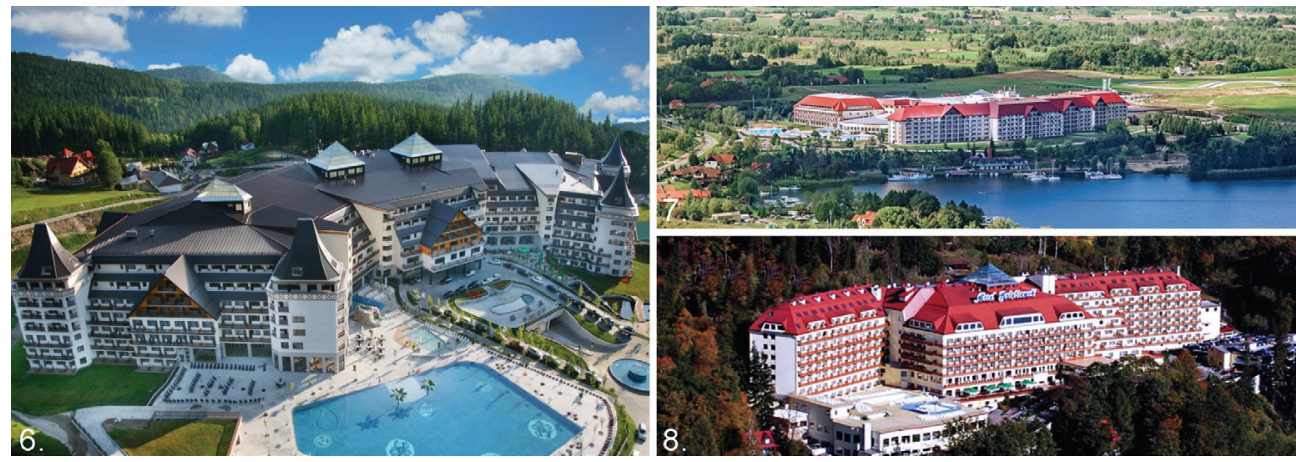

II. 6. Hotel Gołębiewski w Karpaczu (źródło: http://golebiewski.pl)

III. 6. Hotel Gołębiewski in Karpacz

II. 7. Hotel Gołębiewski w Mikołajkach (źródło: http://tripbook.pl)

III. 7. Hotel Gołębiewski in Mikołajki

II. 8. Hotel Gołębiewski w Wiśle (źródło: http://pl.hotelopedia.org/hotel-golebiewski-wisla)

III. 8. Hotel Gołębiewski in Wisla

\begin{tabular}{|c|c|c|}
\hline hotel & Lavish Five-Star Cave Hotel, Shanghai & Crown's 6-star Melbourne Hotel, Melbourne \\
\hline koszt & $£ 345 \mathrm{mln}$ & $\$ 1.5 \mathrm{mld}$ \\
\hline jednostki hotelowe & $\begin{array}{l}380 \text { pokoi, } 19 \text { kondygnacji - w tym dwie } \\
\text { podwodne }\end{array}$ & 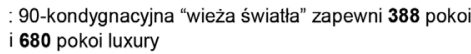 \\
\hline koszt noclegu & od $£ 200$ & od $\$ 350$ \\
\hline zapewnione usługi & $\begin{array}{l}\text { Baseny, centrum sportowe, restauracje, sala } \\
\text { bankietowa, sale konferencyjne }\end{array}$ & $\begin{array}{l}\text { bar, restauracje I ogród na tarasie, zespół basenów, } \\
\text { spa, kasyno, usługi publiczne w parterze }\end{array}$ \\
\hline źródłlo & $\begin{array}{l}\text { http://www.modernghana.com/news/471515/1/now-that- } \\
\text { is-a-groundbreaking-design-the-lavish-345/million-five- }\end{array}$ & $\begin{array}{l}\text { http://www.heraldsun.com.au/news/victoria/crowns-90storey-15b- } \\
\text { queensbridge-hotel-tower-to-reshape-melbourne-cbd/news- }\end{array}$ \\
\hline 9. & $\begin{array}{l}\text { star-cave-hotel-being-built-in-an-abandoned-chinese- } \\
\text { quarry.html }\end{array}$ & story/28696b4b44e4b67f514d112248b23469 \\
\hline
\end{tabular}

II. 9. Przykłady wielkoskalowych hybrydowych obiektów hotelowych (rys. M. Petelenz) III. 9. Examples of large-scale hybrid hotel facilities
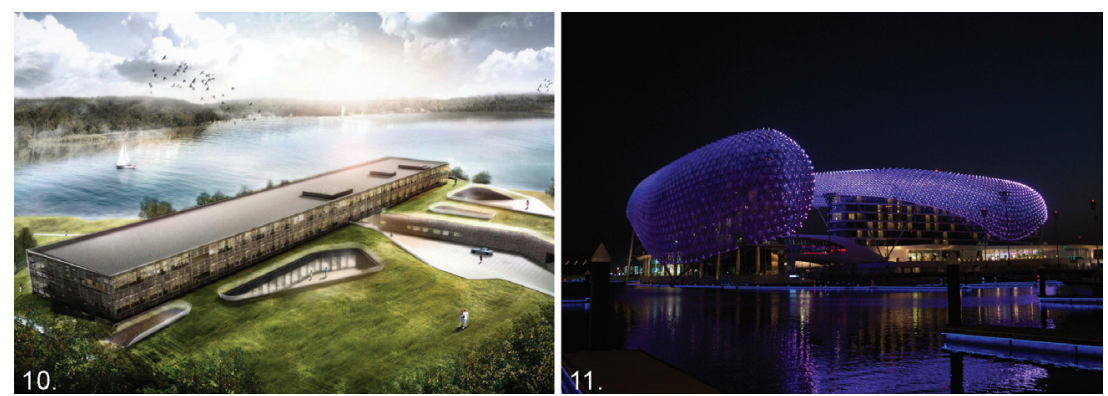

II. 10. Bostalsee Hotel (źródło: http://graftlab.com/portfolio_page/bostalsee)

III. 10. Bostalsee Hotel

II. 11. The Yas Hotel (źródło: http://homesthetics.net/yas-viceroy-abu-dhabi-hotel-asymptotearchitecture)

III. 11. The Yas Hotel 

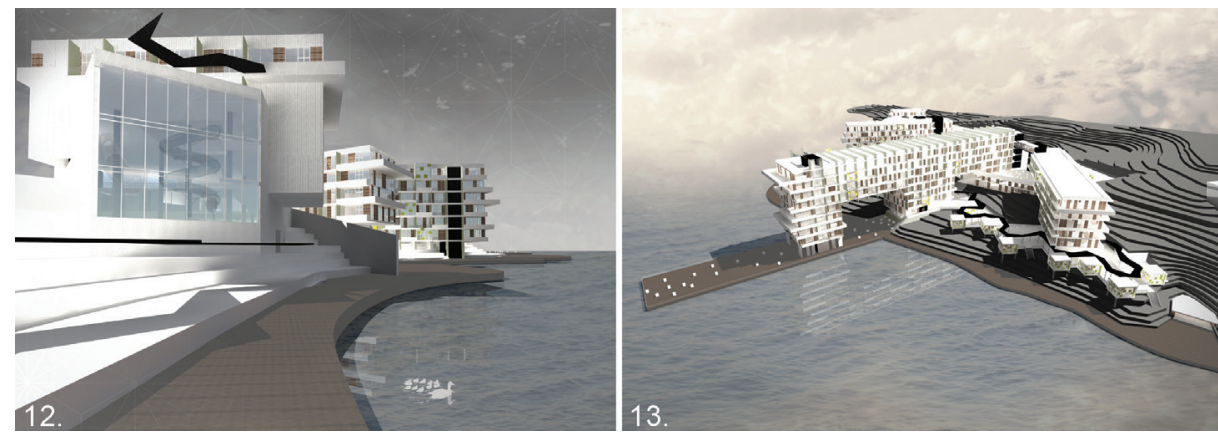

II. 12. Projekt All Seasons Hotel, aut. Małgorzata Petelenz. Widok 3d na pieszą promenadę

(źródło: archiwum własne)

III. 12. Project All Seasons Hotel, by Małgorzata Petelenz. 3d view of the pedestrian promenade

II. 13. Projekt All Seasons Hotel, aut. Małgorzata Petelenz. Widok 3d z góry na cały kompleks

(źródło: archiwum własne)

III. 13. Project All Seasons Hotel, by Małgorzata Petelenz. 3d top view of the whole arrangement
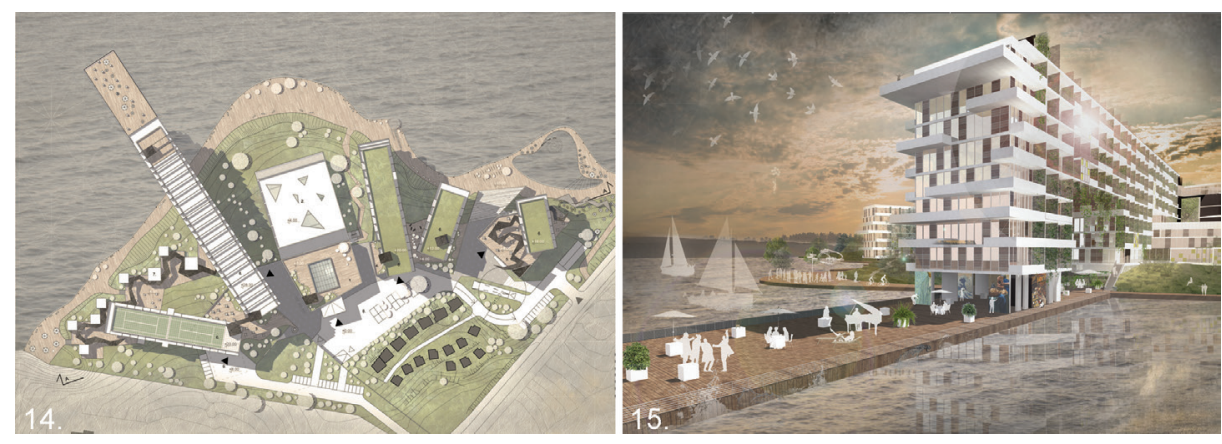

II. 14. Projekt All Seasons Hotel, aut. Małgorzata Petelenz. Rysunek zagospodarowania terenu

(źródło: archiwum własne)

III. 14. Project All Seasons Hotel, by Małgorzata Petelenz. Site plan

II. 15. Projekt All Seasons Hotel, aut. Małgorzata Petelenz. Widok 3d na molo (źródło: archiwum własne)

III. 15. Project All Seasons Hotel, by Małgorzata Petelenz. 3d view of the pier

16.

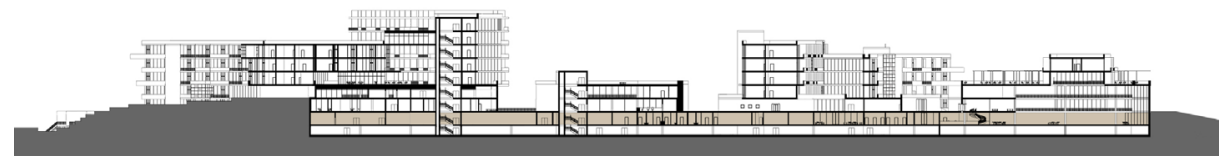

II. 16. Projekt All Seasons Hotel, aut. Małgorzata Petelenz. Schemat przekroju podłużnego (źródło: archiwum własne) III. 16. Project All Seasons Hotel, by Małgorzata Petelenz. Longitudinal section scheme 


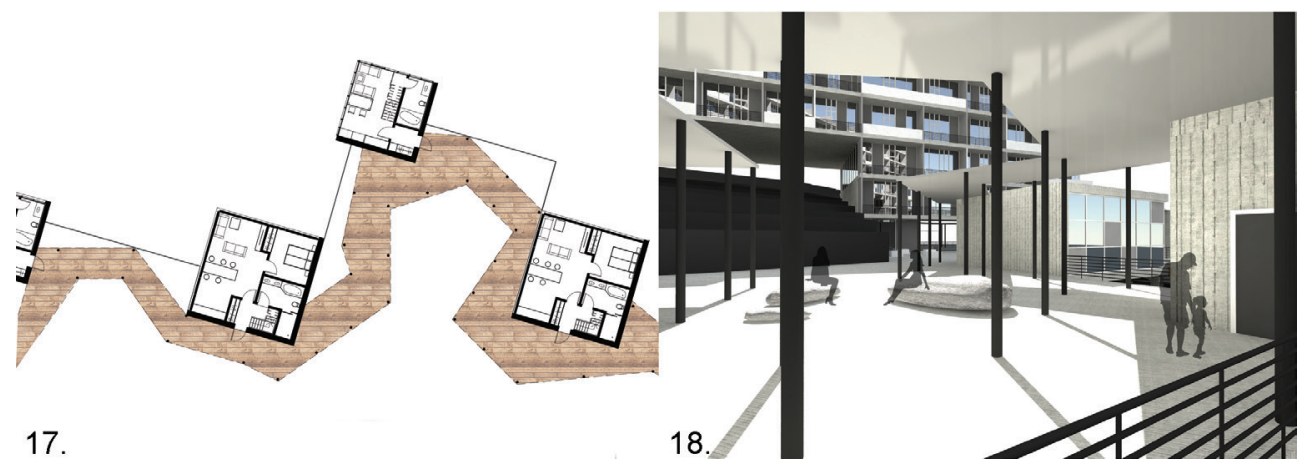

II. 17. Projekt All Seasons Hotel, aut. Małgorzata Petelenz. Fragment planu domków wolnostojących (źródło: archiwum własne)

III. 17. Project All Seasons Hotel, by Małgorzata Petelenz. Fragment of the bungalows plan

II. 18. Projekt All Seasons Hotel, aut. Małgorzata Petelenz. Widok 3d zadaszonej przestrzeni wspólnej domków wolnostojących (źródło: archiwum własne)

III. 18. Project All Seasons Hotel, by Małgorzata Petelenz. 3d view of the roofed common space in the bungalow area
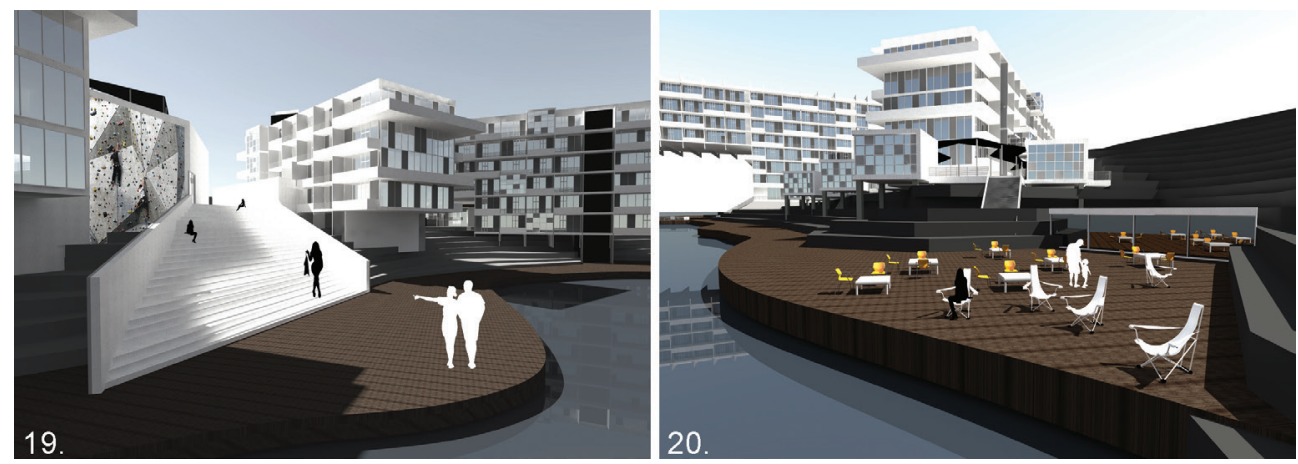

II. 19. Projekt All Seasons Hotel, aut. Małgorzata Petelenz. Widok 3d na pieszą promenadę, schody i ścianę wspinaczkową (źródło: archiwum własne)

III. 19. Project All Seasons Hotel, by Małgorzata Petelenz. 3d view of the pedestrian promenade, stairs and the climbing wall

II. 20. Projekt All Seasons Hotel, aut. Małgorzata Petelenz. Widok 3d na kawiarnię przy promenadzie (źródło: archiwum własne)

III. 20. Project All Seasons Hotel, by Małgorzata Petelenz. 3d view of the café on the promenade 


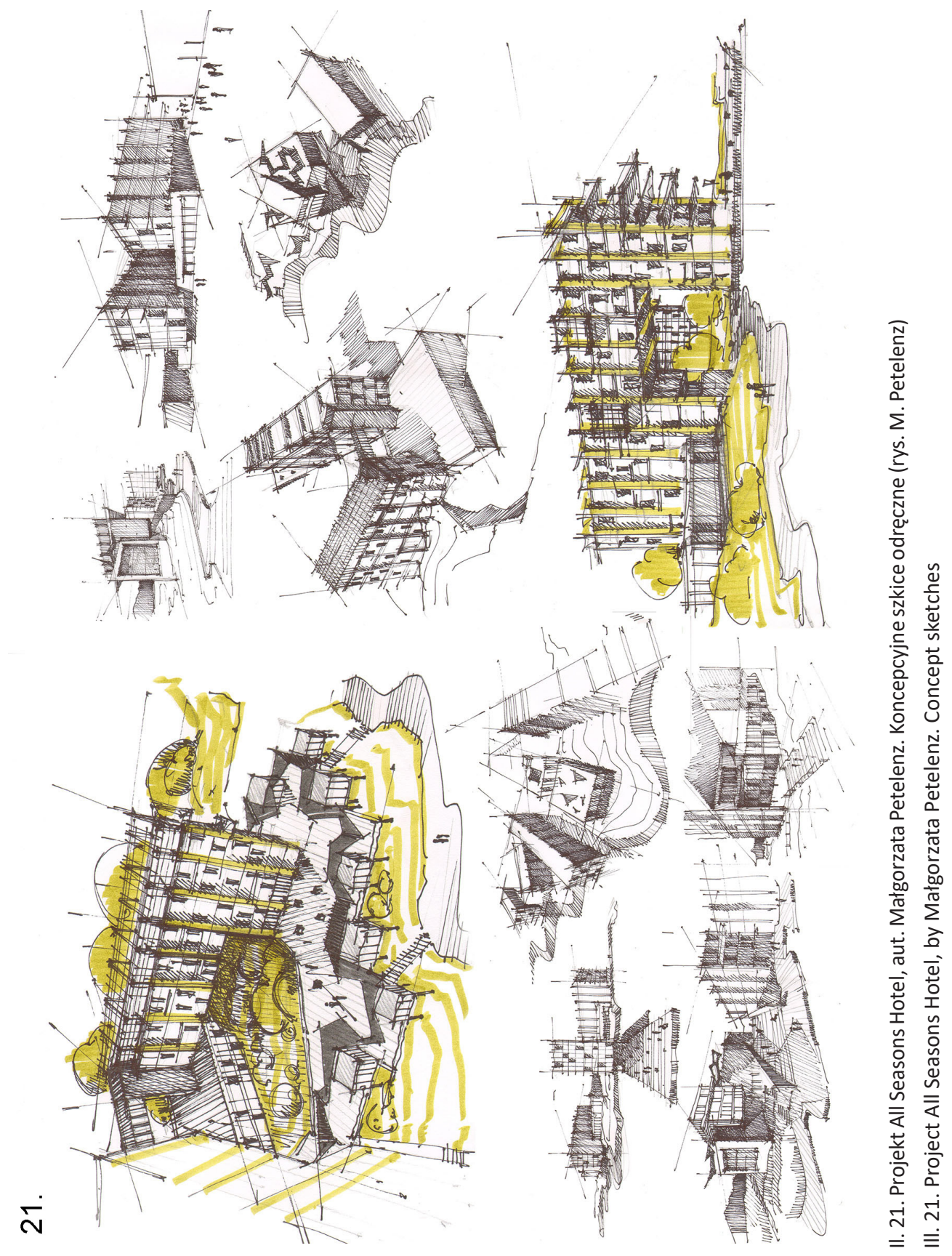




\section{PRZYPISY}

1 „Hotel Babylon”, BBC 2006, S01E01.

2 Projekt dyplomowy w języku angielskim, tytuł oryginalny: „All Seasons Hotel, Hotel, Congress Centre and Recreation Complex by the Rożnowskie Lake, Gródek nad Dunajcem"; autorka: Małgorzata Petelenz; promotorzy: dr hab. inż. arch. Mateusz Gyurkovich oraz Adolf Sotoca Garcia, PhD.Arch., Assoc. Prof. ETSAV; BARCELONA-TECH; rok 2016; Wydział Architektury Politechniki Krakowskiej.

3 D. Johnson, The Ritz Paris's Grand Reopening: A First Look Inside the Newly Renovated Hotel, Vogue Magazine, http://www.vogue.com/13446877/ritz-paris-grand-openingversailles-chanel (dostęp: 20.04.2017); http://www.hoteldevendome.com/fr (dostęp: 25.04.2017).

4 Jednym z momentów, gdy ten rozwój został zatrzymany to czas I wojny w Zatoce Perskiej. Rok 1991 jest określany jako black year przemysłu hotelarskiego; http://www.hospitalitynet. org/news/4017990.html (dostęp: 20.04.2017).

5 D. Johnson, The Ritz Paris's Grand Reopening: A First Look Inside the Newly Renovated Hotel, Vogue Magazine, http://www.vogue.com/13446877/ritz-paris-grand-opening-versailles-chanel (dostęp: 20.04.2017).

6 G.K. Vallen, J.J. Vallen, Check-in Check-Out: Managing Hotel Operations, Second Edition, Published by Prentice Hall, https://www.homeworkmarket.com/sites/default/files/q4/12/06/ htm280_ch01.pdf (dostęp: 20.04.2017).

$7 \mathrm{http}: / /$ setupmyhotel.com/train-my-hotel-staff/front-office-training/76-classification-of-hotels.html (dostęp: 20.04.2017).

8 Ibidem.

9 Intercontinental Hotels \& Resorts, Holiday Inn i Holiday Inn Express, Crowne Plaza, Indigo I dwie sieci hoteli Extended Stay: Staybridge Suites i Candlewood Suites. W całości, oferuje 647 tys. Pokoi na wszystkich kontynentach; http://www.blowuphall5050.com (dostęp: 01.05.2017).

10 Ibidem.

${ }_{11}$ Min. jedno miejsce na 13 miejsc pracy w Europie.

12 An assessment of the economic contribution of the hospitality sector across 31 countries, 2013, http://www.ey.com/Publication/vwLUAssets/The_Hospitality_Sector_in_Europe/\$FILE/EY_The_Hospitality_Sector_in_Europe.pdf (dostęp: 20.04.2017).

${ }^{13}$ G.K. Vallen, J.J. Vallen, Check-in Check-Out..., op.cit.

14 https://seezeitlodge-bostalsee.de (dostęp: 20.04.2017); http://graftlab.com/portfolio_ page/bostalsee (dostęp: 20.04.2017).

${ }^{15} \mathrm{http}: / /$ www.asymptote.net/yas-slide-show (dostęp: 20.04.2017); http://www.dezeen. com/2009/05/14/the-yas-hotel-by-asymptote (dostęp: 20.04.2017).

16 Inspirującym przykładem aktywizacji brzegu jeziora jest projekt nabrzeża Jeziora Paprocany.

17 Zapewnia wygodę i bezpieczeństwo komunikacji kołowej i dostawom technicznym do budynków. 


\section{BIBLIOGRAFIA}

An assessment of the economic contribution of the hospitality sector across 31 countries, 2013, http://www.ey.com/Publication/vwLUAssets/The_Hospitality_Sector_in_Europe/\$FILE/ EY_The_Hospitality_Sector_in_Europe.pdf (dostęp: 20.04.2017).

Błądek Z., Hotele. Programowanie, projektowanie, wyposażenie, Palladium, Poznań 2001. Jabłońska J., Typologia wielkoskalowych wewnętrznych przestrzeni publicznych współczesnych hoteli, „Architectus” 2015, 4(44), s. 61-70, http://www.architectus.arch.pwr.wroc. pl/44/44_06.pdf (dostęp: 20.04.2017).

Johnson D., The Ritz Paris's Grand Reopening: A First Look Inside the Newly Renovated Hotel, Vogue Magazine, http://www.vogue.com/13446877/ritz-paris-grand-opening-versailleschanel (dostęp: 20.04.2017).

O'Gorman K.D., Origins of the Commercial Hospitality Industry: From the fanciful to factual. International Journal of Contemporary Hospitality Management, ISSN 0959-6119 (in Press), https://pure.strath.ac.uk/portal/files/260223/strathprints007647.pdf (dostęp: 20.04.2017). Vallen G.K., Vallen J.J., Check-in Check-Out: Managing Hotel Operations, Second Edition, Published by Prentice Hall, https://www.homeworkmarket.com/sites/default/files/q4/12/06/ htm280_ch01.pdf (dostęp: 20.04.2017).

http://www.asymptote.net/yas-slide-show (dostęp: 20.04.2017).

http://www.attrap-reves.com/en (dostęp: 17.04.2017).

http:// blowuphall5050.com (dostęp: 01.05.2017).

http://www.dezeen.com/2009/05/14/the-yas-hotel-by-asymptote (dostęp: 20.04.2017). https://disneyworld.disney.go.com/resorts/pop-century-resort (dostęp: 14.04.2017). http://www.golebiewski.pl (dostęp: 17.04.2017). http://graftlab.com/portfolio_page/bostalsee (dostęp: 20.04.2017).

http://homesthetics.net/yas-viceroy-abu-dhabi-hotel-asymptote-architecture (dostęp: 15.04.2017).

http://hospitalitynet.org/news/4017990.html (dostęp: 20.04.2017). http:// hoteldevendome.com/fr (dostęp: 25.04.2017). http://pl.hotelopedia.org/hotel-golebiewski-wisla (dostęp: 17.04.2017). http://projects.vanartgallery.bc.ca/publications/Hotel/introduction-to-hotel-typologies (dostęp: 20.04.2017).

https://seezeitlodge-bostalsee.de (dostęp: 20.04.2017).

http://setupmyhotel.com/train-my-hotel-staff/front-office-training/76-classification-of-hotels. html (dostęp: 20.04.2017).

http://telegraph.co.uk (dostęp: 7.05.2017).

http://themantaresort.com (dostęp: 7.05.2017).

http://tripbook.pl (dostęp: 17.04.2017).

http://vogue.com/13446877/ritz-paris-grand-opening-versailles-chanel (dostęp: 14.04.2017). 